\title{
Grafting Neural Precursor Cells Promotes Functional Recovery in an SCA1 Mouse Model
}

\author{
Satyan Chintawar, ${ }^{1}$ Raphael Hourez,${ }^{2 \star}$ Ajay Ravella, ${ }^{1 \star}$ David Gall, ${ }^{2}$ David Orduz, ${ }^{2}$ Myriam Rai, ${ }^{1}$ Don Patrick Bishop,${ }^{2}$ \\ Stefano Geuna, ${ }^{3}$ Serge N. Schiffmann, ${ }^{2}$ and Massimo Pandolfo ${ }^{1}$ \\ ${ }^{1}$ Laboratory of Experimental Neurology and ${ }^{2}$ Laboratory of Neurophysiology, Brussels Free University (ULB), 1070 Brussels, Belgium, and ${ }^{3}$ Department of \\ Clinical and Biological Sciences and Cavalieri Ottolenghi Scientific Institute, University of Turin, Orbassano (TO), 10043 Italy
}

The B05 transgenic SCA1 mice, expressing human ataxin-1 with an expanded polyglutamine tract in cerebellar Purkinje cells (PCs), recapitulate many pathological and behavioral characteristics of the neurodegenerative disease spinocerebellar ataxia type 1 (SCA1), including progressive ataxia and PC loss. We transplanted neural precursor cells (NPCs) derived from the subventricular zone of GFPexpressing adult mice into the cerebellar white matter of SCA1 mice when they showed absent ( 5 weeks), initial (13 weeks), and significant (24 weeks) PC loss. Only in mice with significant cell loss, grafted NPCs migrated into the cerebellar cortex. These animals showed improved motor skills compared with sham-treated controls. No grafted cell adopted the morphological and immunohistochemical characteristics of PCs, but the cerebellar cortex in NPC-grafted SCA1 mice had a significantly thicker molecular layer and more surviving PCs. Perforated patch-clamp recordings revealed a normalization of the PC basal membrane potential, which was abnormally depolarized in sham-treated animals. No significant increase in levels of several neurotrophic factors was observed, suggesting, along with morphological observation, that the neuroprotective effect of grafted NPCs was mediated by direct contact with the host PCs. We postulate that a similar neuroprotective effect of NPCs may be applicable to other cerebellar degenerative diseases.

\section{Introduction}

Spinocerebellar ataxia type 1 (SCA1) is one of the hereditary neurodegenerative disorders caused by the expansion of a CAG trinucleotide repeat, which is translated into a polyglutamine (polyQ) tract in the corresponding protein (Orr and Zoghbi, 2007). It is an autosomal dominant usually late-onset disorder characterized by progressive cerebellar ataxia associated with variable degrees of pyramidal, extrapyramidal, and oculomotor abnormalities, peripheral neuropathy, and cognitive impairment. Pathologically, loss of cerebellar Purkinje cells (PCs) and of neurons in the brainstem are typical findings (Watase et al., 2002). The mutated gene in SCA1, AXN1, encodes the ataxin-1 protein, which is thought to be involved in transcription regulation and RNA processing. Ataxin- 1 is localized in the nucleus of neurons, in the cytoplasm of non-neuronal cells, and in both the nucleus and cytoplasm of cerebellar PCs. The nuclear localization of ataxin- 1 has been shown to be essential for pathology. The pathogenesis of SCA1 involves a toxic gain-of-function effect of the expanded polyQ tract along with dominant-negative effects due to altered functionalities of the mutated protein (Bowman et al., 2007).

The first SCA1 mouse model, developed by Burright et al. (1995), was based on a multicopy transgene expressing a mutated

\footnotetext{
Received Feb. 7, 2009; accepted Sept. 1, 2009.

This work was supported by the Belgian Scientific Research Funds. We thank Dr. J. M. Vanderwinden for expertise and technical assistance to microscopy, and we thank Ana Lopes da Cruz for animal technical assistance.

${ }^{*}$ R.H. and A.R. contributed equally to this work.

Correspondence should be addressed to Prof. Massimo Pandolfo, Laboratory of Experimental Neurology, Brussels Free University (ULB), Route de Lennik 808, 1070 Brussels, Belgium. E-mail: massimo.pandolfo@ulb.ac.be. DOl:10.1523/JNEUROSCI.0647-09.2009

Copyright $\odot 2009$ Society for Neuroscience $\quad$ 0270-6474/09/2913126-10\$15.00/0
}

human ataxin-1 with an expanded polyQ tract (30 copies of a transgene encoding ataxin-1 with 82 glutamines in the B05 line, used in the present study) under the control of the PC-specific Pcp2 promoter. This mouse model develops a progressive motor disorder starting at about 5 weeks of age, before the appearance of any alteration of cerebellar morphology. Pathological abnormalities of PCs, in the form of a shrunken dendritic tree and migration of the cell body into the molecular layer, become clearly visible by 12 weeks of age, along with an initial decline in PC number. A significant PC loss (approximately a third) occurs by 24 weeks of age.

No treatment is currently available for SCA1. Patients experience progressive limitations in their activities, lose the ability to walk, and eventually become bedridden and fully dependent. In the present study, we wished to explore the potential of neural stem cell transplantation as a therapeutic approach for SCA1 by testing it in the B05 transgenic model. We considered that, even if effective treatments will be developed with better understanding of SCA1 pathogenesis, stem cell therapy remains an attractive option, as it may provide additional neuroprotection and possibly promote regeneration. In addition, relatively few studies (5) have addressed the effects of stem cell transplantation in cerebellar disorders compared with studies in diseases affecting other brain areas, including several neurodegenerative (McBride et al., 2004; Roberts et al., 2006; Yasuhara et al., 2006; Redmond et al., 2007; Corti et al., 2007, 2008), neuroinflammatory (Pluchino et al., 2003), and other neurological insults (Jeong et al., 2003; Cummings et al., 2005; Karimi-Abdolrezaee et al., 2006; Lee et al., 2007a,b).

For our transplantation experiments, we used neural progenitor cells (NPCs) derived from the subventricular zone (SVZ) of 
adult mice. NPCs are a mixture of neural stem cells and early progenitor cells that can be isolated from specific regions of the adult mammalian brain (the subventricular zone of the lateral walls of lateral ventricles and the subgranular zone in the dentate gyrus of hippocampus) (Gritti et al., 1996; Gage, 2002; Taupin and Gage, 2002; Lie et al., 2004). NPCs possess the potential of generating mature neural and glial progenies (multipotentiality) and their stem cell component has an indefinite self-renewal property. The donor mice we used have the same strain background as the B05 mice ( FBV/N), eliminating any requirement for immunosuppression in grafted animals, and express the green fluorescent protein (GFP) in all their cells, providing a simple marker to trace transplanted cells. Kidney fibroblasts from the same strain were used in control transplantation experiments to evaluate any general, non-NPC-specific effect of grafted cells.

Our results indicate that transplanted NPCs survived and integrated into the recipient cerebellar cortex only in animals that had already suffered a significant PC loss at the time of transplantation. In these mice, NPCs induced behavioral amelioration, promoted survival of PCs, improved cerebellar morphology, and restored a normal PC excitability.

\section{Materials and Methods}

\section{Isolation and culture of NPCs}

NPCs were derived from the SVZ of adult mice as described by Gritti et al. (1999) and modified as follows. Four- to eight-week-old FVB/N mice expressing GFP under $\beta$-actin promoter (The Jackson Laboratory) were anesthetized by Avertin (i.p.) and killed by cervical dislocation. Brains were removed and the thin layer of tissue surrounding the ventricles was cut, dissected into small pieces, and cultured in media containing 20 $\mathrm{ng} / \mathrm{ml}$ recombinant human EGF and $10 \mathrm{ng} / \mathrm{ml}$ recombinant human bFGF (Peprotech). Big spherical clusters were ready to dissociate 7-10 d after isolation. Neurospheres were mechanically dissociated every $4-5 \mathrm{~d}$ and plated in fresh growth medium. They were assessed for self-renewal and multipotentiality as described earlier (see supplemental Methods, available at www.jneurosci.org as supplemental material). NPCs of passage 4-8 were used for transplantation. For detailed procedure for isolation and characterization of NPCs, refer to supplemental material, available at www.jneurosci.org.

\section{Immunocytochemistry}

Undifferentiated and differentiated NPC cultures seeded on matrigel were fixed with $4 \%$ paraformaldehyde and incubated with $0.1 \%$ Triton $\mathrm{X}-100$ for $15 \mathrm{~min}$. Cultures were then incubated overnight at $4^{\circ} \mathrm{C}$ with primary antibodies: nestin (Millipore Bioscience Research Reagents) as marker for undifferentiated cells, MAP-2 (Sigma) as marker for neurons, GalC (Millipore Bioscience Research Reagents) as marker for oligodendrocytes, and GFAP (DakoCytomation) as marker for astrocytes. Antibodies were detected using Cy3-conjugated IgGs. No antibody was needed for GFP, as the native GFP signal was detectable. In all the cultures, DAPI (4',6-diamidino-2-phenylindole) was used to counterstain cell nuclei. Slides were mounted using FluorSave (Calbiochem).

\section{Stereotaxic transplantation}

Five-, thirteen-, and twenty-four-week-old B05 transgenic SCA1 mice and wild-type (wt) mice of same age were matched for sex and weight. NPCs were transplanted by stereotactic surgery under deep Avertin anesthesia. Neurospheres were dissociated the day before surgery, cells were pelleted to remove the medium and washed twice in L15 medium before being resuspended at 50,000 cells/ $\mu$ l. Cells from 2-3 donor mice were pooled and were grafted within a maximum of $2 \mathrm{~h}$ after being resuspended. Fresh batches of cells were continuously generated according to need. Injections were done using a $10 \mu \mathrm{l}$ Hamilton syringe and a microstereotactic injection system (David Kopf Instruments). Each mouse received three cellular implants into the cerebellar white matter at the following coordinates in reference to bregma: (1) anterior-posterior (A$\mathrm{P}),-6.24$; mediolateral $(\mathrm{M}-\mathrm{L}), 0$; dorsal-ventral (D-V), -3; (2) A-P,
-6.24 ; $\mathrm{M}-\mathrm{L},-2$; D-V, -3 ; and (3) A-P, $-6.24 ; \mathrm{M}-\mathrm{L},+2$; D-V, -3 . Before grafting, ink (Matfer) was injected at the same coordinates in control animals, which were immediately killed for microscopic examination of brain slices to determine target accuracy. Each grafted animal received 100,000 cells in a $2 \mu \mathrm{l}$ volume at each of the three injection sites (SCA1-NPC, WT-NPC). Sham-treated mice received $2 \mu \mathrm{l}$ of L15 medium (SCA1-L15, WT-L15). The needle was placed in situ for $2 \mathrm{~min}$ before and after injection before being slowly removed. At the end of the grafting, cell viability was verified by trypan blue exclusion and hemocytometer. Mice did not receive any immunosuppressive therapy and were killed 8 weeks after transplantation. As a control cell line, primary fibroblasts were grafted. They were isolated from the kidneys of FVB/N mice expressing GFP under $\beta$-actin promoter and cultured as described by Pluchino et al. (2003) (SCA1-FBR, WTFBR). All procedures respected regulations and guidelines of the Belgian state and European Union and were approved by the local animal ethics committee (CEBEA).

\section{Motor behavior assessment}

Accelerating rotarod test. Four and eight weeks after transplantation, sexand weight-matched SCA1-NPC, SCA1-L15, SCA1-FBR, WT-NPC, and WT-L15/WT-FBR mice were tested on the rotarod (Ugo Basile), which underwent linear acceleration from 4 to $40 \mathrm{rpm}$. Animals were scored by an observer who was unaware of their transgenic and treatment status for their latency to fall (seconds) or until they made two consecutive revolutions while holding onto the rod. Each trial lasted for a maximum of $5 \mathrm{~min}$ and mice were rested for minimum $10 \mathrm{~min}$ between trials to avoid fatigue. Mice underwent four trials per day for 4 consecutive days, and the mean of each day was considered for statistical analysis.

Grip strength test. Grip strength was assessed on a grip strength meter (Bioseb) 8 weeks after transplantation. Grip strength of the front paws was tested by holding the mouse over the grid and moving it down until its front legs grasped the grid. The mouse was then pulled following the axle of the sensor until it released the grid and the maximum force exerted appeared on the display. Individual animals were exposed to five successive measurements by a blinded observer to their transgenic and treatment status. The mean of the three highest values was used for statistical analysis.

\section{Brain processing}

After behavioral testing, mice were deeply anesthetized with Avertin (i.p.) and transcardially perfused with PBS followed by $4 \%$ paraformaldehyde (PFA) in $0.1 \mathrm{~m}$ phosphate buffer. Brains were isolated and left in $4 \%$ PFA for $2 \mathrm{~h}$ followed by $20 \%$ sucrose for $24 \mathrm{~h}$. Eighteen micrometer sagittal cryostat cerebellar sections were mounted on Superfrost Plus (Menzel-Glaser) slides.

\section{Histology and immunofluorescence on brain sections}

Cryostat cerebellar sections were incubated in a blocking solution containing $5 \%$ donkey serum with $0.3 \%$ Triton $\mathrm{X}-100$ for $2 \mathrm{~h}$, followed by primary antibodies at $4^{\circ} \mathrm{C}$ for $24 \mathrm{~h}$ (except for GFP). Primary antibodies included: mouse monoclonal antibody NeuN (Millipore Bioscience Research Reagents) to detect mature neurons, GFAP (Sigma) for astrocytes, calbindin D-28K (Swant) specific for PCs. The secondary antibody was a donkey anti-mouse IgG conjugated with the fluorescent dye Cy3. Alexa Fluor 488 dye-labeled rabbit anti-GFP conjugate (Invitrogen) was used to detect implanted NPCs and derived cells. Tissues were washed thoroughly, incubated with DAPI to stain cell nuclei and mounted with FluorSave. Sections were visualized by laser scanning confocal microscope (Zeiss LSM 510 META). For all immunohistochemistry procedures, adjacent sections were processed in an identical manner, but excluding the primary antibody to serve as negative controls.

\section{Quantitative real-time $R T$-PCR}

For RNA and protein extraction, deeply anesthetized mice were killed by cervical dislocation and cerebellar tissue was cut into two equal halves and processed separately for RNA and protein extraction. Total RNA from cerebellum was extracted by RNeasy Lipid Tissue Mini Kit (Qiagen) as recommended by the manufacturer. All RNA samples were treated 
with RNase-Free DNase Set (Qiagen) and quantified afterward by measuring the optical density (NanoDrop ND-1000 Spectrophotometer, NanoDrop Technologies). Two hundred nanograms of total RNA were reverse transcribed in $40 \mu \mathrm{l}$ of mixture that included $40 \mathrm{U}$ of RNaseIN (Promega) and $200 \mathrm{U}$ of M-MLV reverse transcriptase (Invitrogen) in the presence of random hexamer (GE Healthcare) and dNTP mixture (Invitrogen). We performed quantitative real-time PCR using Power SYBR Green (from Applied Biosystems) on the ABI 7500 Fast Real Time PCR System (Applied Biosystems). Primers used for BDNF, GDNF, NGF, and NT-3 were purchased from Qiagen as QuantiTect Primer Assay. RNA was standardized relative to RER1 and RPL-13 mRNA using qBase 1.3.4 (Jan Hellemans and Jo Vandesompele, Center for Medical Genetics, Ghent University Hospital, Ghent, Belgium). Data are normalized to the mRNA level in SCA1-L15 mice $(=100 \%)$ for each gene.

\section{Western blot analysis}

Tissues were homogenized in T-PER tissue protein extraction reagent (Pierce) for total proteins extraction. Protein quantification was done using MicroBCA Protein Assay (Pierce). Samples were run on a $12-16 \%$ SDS-PAGE, blotted, and probed with rabbit anti-BDNF, -NT3, or -NGF (Santa Cruz Biotechnology); goat anti-GDNF (R\&D Systems); or mouse anti-actin (Sigma-Aldrich). After incubating with the appropriate horseradish peroxidase conjugated second antibody (anti-rabbit, anti-goat, or anti-mouse; Santa Cruz Biotechnology), bands were visualized by using SuperSignal West Pico Chemiluminescent Substrate (Pierce). Signals were acquired by using a flat scanner and analyzed by using NIH ImageJ $1.34 \mathrm{~s}$ program (National Institutes of Health). Actin was used to normalize the amount of protein.

\section{In vitro electrophysiology}

Slice preparation. Experiments were performed on 32- to 34-week-old SCA1 and wt mice. Acute cerebellar sagittal slices were prepared from animals anesthetized with halothane (Sigma) as described in published protocols (D'Angelo et al., 2001). After decapitation, the vermis was removed and mounted in a chamber filled with cooled $\left(0-3^{\circ} \mathrm{C}\right)$, oxygenated artificial CSF (ACSF) containing the following (in $\mathrm{mm}$ ): $120 \mathrm{NaCl}$, $26 \mathrm{NaHCO}_{3}, 2 \mathrm{KCl}, 2 \mathrm{CaCl}_{2}, 1.19 \mathrm{MgSO}_{4}, 1.18 \mathrm{NaH}_{2} \mathrm{PO}_{4}$, and 11 glucose (osmolarity 285-295 mOsm $/ \mathrm{kg}$, pH 7.4, when equilibrated with $95 \%$ $\left.\mathrm{O}_{2}-5 \% \mathrm{CO}_{2}\right)$. Thick sagittal slices $(270 \mathrm{~mm}$ ) were cut by using a VT1000S slicer (Leica Instruments) and incubated in oxygenated ACSF at $32^{\circ} \mathrm{C}$ for at least $30 \mathrm{~min}$ before they were transferred to the recording chamber (1.5 $\mathrm{ml}$ ) mounted on the stage of an upright microscope (Axioskop2; Zeiss), where they were continuously perfused with oxygenated ACSF at room temperature $\left(20-25^{\circ} \mathrm{C}\right)$.

Perforated-patch recordings. Current-clamp recordings from PCs were performed at room temperature using the perforated patch whole-cell configuration of the patch-clamp technique. Purkinje cells were visually identified and recorded by using the Amphotericin B perforated-patch configuration of the patch-clamp technique. Patch pipettes were made of borosilicate capillary tubing (model 1403547; Hilgenberg) pulled on a P-2000 micropipette puller (Sutter Instrument) and presented resistances of 2-4 M $\Omega$ when filled with the patch pipette solution containing the following: $80 \mathrm{~mm} \mathrm{~K}_{2} \mathrm{SO}_{4}, 10 \mathrm{~mm} \mathrm{NaCl}, 15 \mathrm{~mm}$ glucose, and $5 \mathrm{~mm}$ HEPES (osmolarity $230 \mathrm{mOsm} / \mathrm{kg}$, $\mathrm{pH}$ adjusted to 7.2 with $\mathrm{KOH}$ ). A final $0.52 \mu \mathrm{M}$ concentration of Amphotericin B was obtained by adding $4 \mu \mathrm{l}$ from a $65 \mathrm{~mm}$ Amphotericin B stock solution made in DMSO to $500 \mu \mathrm{l}$ of the pipette solution. The pipette solution was kept cold and in the dark and changed every $2 \mathrm{~h}$ to avoid degradation of Amphotericin B. Recordings were performed in both fast current- and voltage-clamp modes with an EPC 10 amplifier (HEKA) including an analog-to-digital converter and an analog Bessel low-pass filter 3-pole. Protocol generation and data acquisition were made with Pulse 8.65 (HEKA). Spontaneous and depolarization-evoked potential signals were filtered at $4 \mathrm{kHz}$ and digitally sampled at $20 \mathrm{kHz}$.

\section{Confocal imaging and image analysis}

In a separate series of whole-cell recordings used for morphological reconstruction, the intracellular solution contained the following (in $\mathrm{mM}$ ): 126 K-gluconate, $0.05 \mathrm{CaCl}_{2}, 0.15 \mathrm{BAPTA}, 4 \mathrm{NaCl}, 1 \mathrm{MgSO}_{4}, 15$ glucose, 5 HEPES, 3 MgATP, 0.1 GTP (pH adjusted to 7.2 with $\mathrm{KOH}$ ), and $0.4 \%$ biocytin (Sigma-Aldrich). Purkinje cells were filled with biocytin during
$15 \mathrm{~min}$ and fluorescence was subsequently revealed by cytochemistry. To this end, slices were fixed by immersion in $4 \%$ paraformaldehyde overnight. Biocytin was revealed with streptavidin-conjugated fluorescein isothiocyanate (FITC; Jackson ImmunoResearch) diluted 1:200. After three rinses in TBS, slices were mounted on coverslips with FluorSave mounting medium (Calbiochem). LSM510 NLO multiphoton confocal microscope fitted on an Axiovert M200 inverted microscope equipped with C-Apochromat $40 \times / 1.2$ N.A. and $63 \times / 1.2$ N.A. water-immersion objectives (Zeiss). The $488 \mathrm{~nm}$ excitation wavelength of the Argon/2 laser, a main dichroic HFT 488, and a bandpass emission filter (BP500$550 \mathrm{~nm}$ ) were used for selective detection of the green fluorochrome. The $543 \mathrm{~nm}$ excitation wavelength of the HeNe1 laser, a main dichroic HFT 488/543/633, and a long-pass emission filter (LP560 nm) were used for selective detection of the red fluorochrome. The nuclear stain DAPI was excited in multiphotonic mode at $760 \mathrm{~nm}$ with a Mai Tai tunable broadband laser (Spectra-Physics) and detected using a main dichroic HFT KP650 and a bandpass emission filter (BP435-485 nm). Sequential optical sections of $2048 \times 2048$ pixels were taken at $0.8 \mu \mathrm{m}$ intervals along the $z$-axis to allow $3 \mathrm{D}$ reconstruction. Possible distortion caused by the histological processing has been shown to cause less then $5 \%$ error on estimated length (Roth and Häusser, 2001). To avoid any bias, data acquisition and analysis were performed in the absence of knowledge of the experimental conditions. Cellular volumes were computed by evaluating the number of voxels inside cells. For each cell, the threshold value defining the cell surface was set using the ISODATA algorithm implemented in ImageJ software (NIH). The total number of voxels inside the cell was then evaluated using the VoxelCounter plugin (W. Rasband, $\mathrm{NIH}$ ) for ImageJ and multiplied by the unitary voxel volume. Using the same software, maximal sagittal extension of PC was computed.

\section{Stereology}

The total number of PCs in mouse cerebellum was estimated by designbased stereology adopting a systematic random sampling scheme and the optical disector counting method as described earlier (Geuna, 2000; Kubínová and Janácek, 2001; von Bartheld, 2002). Twenty-four-weekold grafted SCA1 and WT mice were transcardially perfused 8 weeks later and then brains were cryostat sliced at $18 \mu \mathrm{m}$. Cerebellar sections of WT-NPC, -FBR, SCA1-L15, -FBR, -NPC were selected by systematic random sampling over the entire cerebellum. Sections were immunostained to reveal PCs soma and their dendrites in the molecular layer (ML). Using confocal laser scanning microscope, the optical disector method was applied to identify and count PC tops (supplemental Fig. 4, available at www.jneurosci.org as supplemental material) and thus to calculate average PC density $\left(N_{\mathrm{v}}\right)$. Then the reference volume $\left(V_{\text {ref }}\right)$ of $\mathrm{PCL}+\mathrm{ML}$ was estimated using the Cavalieri principle. Finally the total number $(N)$ of PCs was calculated as $N=V_{\text {ref }} \times N_{\mathrm{v}}$ (von Bartheld, 2002). The same principles were applied while estimating the total number of PCs in PCL, of ectopic PCs, and of grafted NPCs and their migration in the cerebellar cortex. For counting NPCs and derived cells, identification was performed by immunostaining against anti-GFP and colocalization with DAPI.

\section{Image processing software packages}

The datasets generated by confocal microscopy were merged and displayed with the Zeiss LSM510 software and exported in TIFF image format.

The datasets generated by fluorescence microscopy were merged and displayed with the Axiovison software (Zeiss) and exported in TIFF image format. Image processing was performed using ImageJ software (NIH). For final representation of figures, images and histograms were assembled using Adobe Illustrator CS3 and exported in TIFF format.

\section{Statistics}

Results are represented as mean \pm SEM. Comparisons among groups for accelerating rotarod test, grip strength test (see Figs. 3, 4), and quantitative analysis of PC volume and maximal sagittal extension (see Fig. 5) were made using one-way ANOVA followed by an LSD-Fischer post hoc test using the Statistica Software (Statsoft). Basal membrane potential between SCA1-NPC and SCA1-L15 groups (see Fig. 6) was compared using Student's $t$ test. Histograms were generated using SigmaPlot 10.0. ${ }^{\star} p<0.05,{ }^{* *} p<0.01,{ }^{* *} p<0.001$. 
A
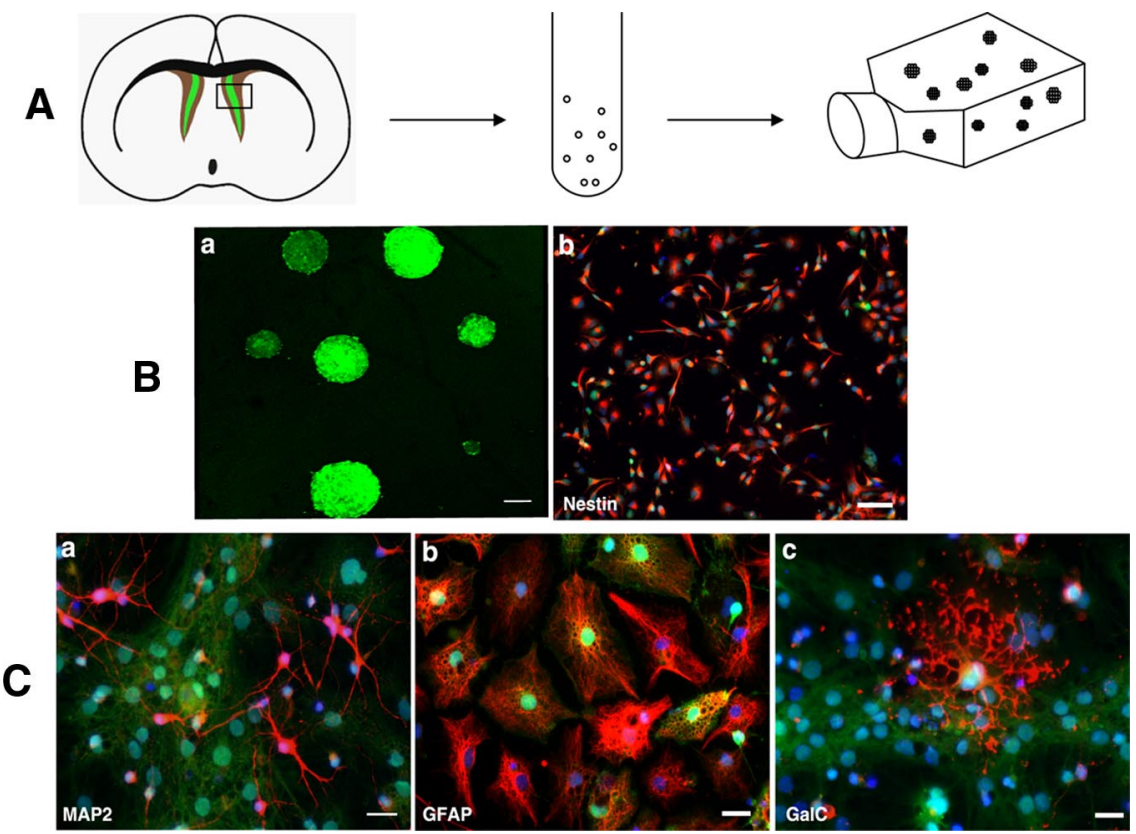

Figure 1. Culture and characterization of adult neural precursor cells. $A$, Schematic representation of extraction of NPCs from subventricular zone of green mouse expressing GFP under $\beta$-actin promoter. $\boldsymbol{B}$, Dissociated single cells proliferate and form spherical clusters which express GFP, as shown by projection of Z stack images acquired by confocal microscopy (a). Nearly all cells in proliferating culture express Nestin $(\boldsymbol{b})$, an undifferentiated neural cell marker. $\boldsymbol{C}$, When undergone differentiation, NPCs express mature neuronal marker MAP2 (a), astrocytic marker GFAP $(\boldsymbol{b})$, and mature oligodendrocytic marker GalC (c). Scale bars: Ba, 100 $\mu \mathrm{m} ; \boldsymbol{B} \boldsymbol{b}, 50 \mu \mathrm{m} ; \boldsymbol{C a}-\boldsymbol{C c}, 20 \mu \mathrm{m}$.
A

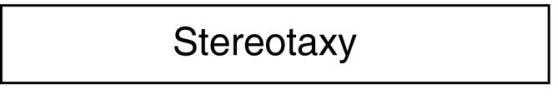

5 wks 13 wks 24 wks

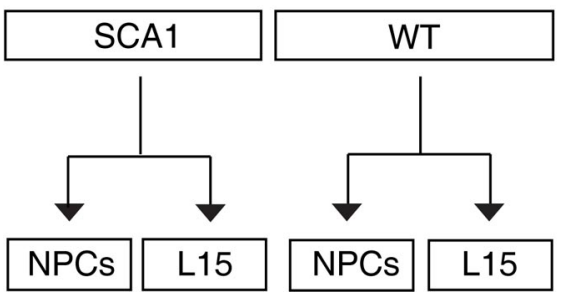

B

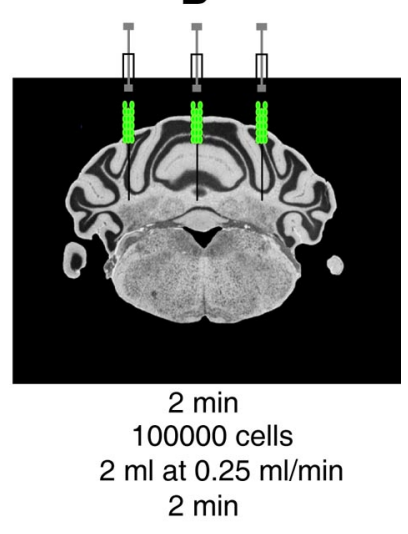

Figure 2. Stereotactic transplantation of NPCS. A, NPCs in L15 medium were grafted in wild-type and SCA1 mice of 5, 13, and 24 weeks of age. In sham mice, only L15 medium was injected. $\boldsymbol{B}$, Schema of coronal view of mouse cerebellum depicting site of injections. Three deposits ( 2 laterally and 1 in vermis) each of 100,000 cells were made in cerebellar white matter with the interval of $2 \mathrm{~min}$ after the insertion of needle and before its removal (for coordinates, see Materials and Methods).

\section{Results}

Isolation and culture of adult murine neural precursor cells Adult NPCs, a mix of stem and early progenitor cells, were derived from the SVZ of transgenic FVB/N mice (same strain background as the SCA1 transgenics) that express GFP under the $\beta$-actin promoter, and grown as spherical clusters or neurospheres (Fig. 1A). NPCs self-renewing ability was assessed by clonogenic assay where $50 \%$ of dissociated single cells formed neurospheres (Fig. $1 B$ ). In proliferation medium, all cells in neurospheres strongly expressed the neural stem/progenitor cell marker nestin (Fig. $1 B$ ). After triggering in vitro differentiation by growth factor withdrawal, nestin was no longer expressed. We confirmed the tripotent nature of our NPCs by their ability to generate differentiated cells expressing neuronal, astrocytic, or oligodendrocytic markers (Reynolds and Weiss, 1992; Morshead et al., 1994; Weiss et al., 1996) (Fig. 1C). In proliferation media, cultures were consistently passaged every 4-5 d, when neurospheres were $>150 \mu \mathrm{m}$ in size but their core had not yet turned brownish. NPCs at passage $4-8$ were used for transplantation.

Transplantation of NPCs improves the motor phenotype of SCA1 mice

The B05/+ SCA1 transgenic mouse model was described by Burright et al. (1995). In these animals, expression of mutated human ataxin-1 containing an expanded polyglutamine (82Q) stretch is specifically directed to cerebellar PCs. B05 mice start showing motor abnormalities at 5 weeks of age, when cerebellar pathology is not yet observed. PC loss begins at 13 weeks and is significant at 24 weeks. At 24 weeks, many surviving PC are morphologically abnormal and are heterotopically located in the molecular as well as granule cell layer (Clark et al., 1997).

NPCs were stereotaxically grafted into the cerebellar white matter of 5-, 13-, and 24-week-old SCA1 mice and into wildtype mice of the same age (SCA1-NPC and WT-NPC groups). Three deposits of 100,000 cells each were made. In control-treated SCA 1 and wt mice, only vehicle (L15 medium) was injected (SCA1-L15 and WT-L15 groups) (Fig. 2). Motor skills were evaluated on the accelerating rotarod (4-40 rpm, four trials per day for 4 d) 4 weeks after transplantation by an observer who was unaware of their transgenic status and of the treatment they had received. When grafted at 5 and 13 weeks, SCA1-NPC mice showed no motor improvement when compared with the sham-treated (SCA1-L15) group (Fig. 3A,B). However, SCA1 mice grafted with NPCs at 24 weeks performed significantly better than SCA1-L15 mice 4 weeks after grafting and continued to do so 8 weeks later (Fig. 3C). Complementary to the accelerating rotarod, we used the grip strength test 8 weeks after transplantation (Fig. 3D). SCA1-NPC mice applied more force while leaving the grid than sham-treated mice, suggesting that they had better coordination and thus higher grip strength. Thus, NPCs implantation partially rescued the ataxic phenotype of SCA1 mice at an advanced stage of the disease, when a significant PC loss had occurred. To exclude that this effect was nonspecific to NPCs, we grafted 24-week-old mice with kidney fibroblasts from the same donor strain (SCA1-FBR mice). SCA1-FBR mice did not show improvement, neither at the accelerating rotarod, nor at the grip strength tests (Fig. $4 A, B$ ), and always performed similarly to sham-treated (L15) animals. 


\section{Rescue of mutant Purkinje cells and} dendritic arbors by grafted NPCs

At 24 weeks, SCA1 mice show significant PCs loss, many remaining PCs have ectopically located cell bodies and a shrunken dendritic tree, with severe reduction in molecular layer thickness (Clark et al., 1997). We compared the morphology of the cerebellar cortex of WT, SCA1-L15, and SCA1-NPC mice. The PC layer appeared more uniform with fewer ectopic PCs in SCA1-NPC mice compared with the sham-treated group. Dendritic arbors also looked better preserved in treated mice.

To obtain quantitative data supporting these visual impressions, we estimated the number of surviving PCs in the cerebella of SCA1-L15, SCA1-NPC, and WT mice by stereological methods (Table 1). Thirty-two-week-old SCA1 (L15 and FBR) mice had $60 \%$ less PCs in the PC layer than WT mice of the same age. Taking into account still surviving, but ectopically located PCs in the molecular and in the granule cell layer, these animals had a 45\% PC loss. NPC-grafted SCA1 mice had a significantly higher number of PCs in the PC layer and a lower number of heterotopically located PCs. We estimate that NPC grafting rescued $50 \%$ of PCs that would otherwise have been lost and also reduced ectopic PCs by $35 \%$.

To estimate PC morphology, we determined the total volume and the sagittal extension of dendrites of biocytin-filled PCs from 32-week-old WT $(n=5)$, SCA1-L15 $(n=5)$, SCA1-FBR $(n=5)$, and SCA1-NPC $(n=9)$ mice (Fig. $5 A-C)$. Again, cells from SCA1-NPC mice showed a significant improvement compared with SCA1-L15 and SCA1-FBR controls.

To determine whether several neurotrophic factors might have played a role in the effects of NPC transplantation, we quantified mRNA by qRT-PCR but were unable to find any difference between SCA1-L15 and -NPC animals for BDNF, GDNF, NGF, and NT-3 (see supplemental Fig. 1, available at www.jneurosci.org as supplemental material) Western blotting also did not show any change at protein level for BDNF, GDNF, NT3, and NGF precursor between 2 SCA1 groups (see supplemental Fig. 2, available at www.jneurosci.org as supplemental material).

\section{Migration and homing of grafted NPCs}

Mice were killed by transcardiac perfusion 8 weeks after transplantation. By GFP immunohistochemistry, we observed that in WT-NPC mice of all ages, grafted cells remained in the white matter and did not migrate to the cerebellar cortex (Fig. 6A-C; supplemental Fig. 3, available at www.jneurosci.org as supplemental material). No cell expressed nestin and nearly all cells acquired an astrocytic phenotype and expressed GFAP (Fig. $6 H$ ).
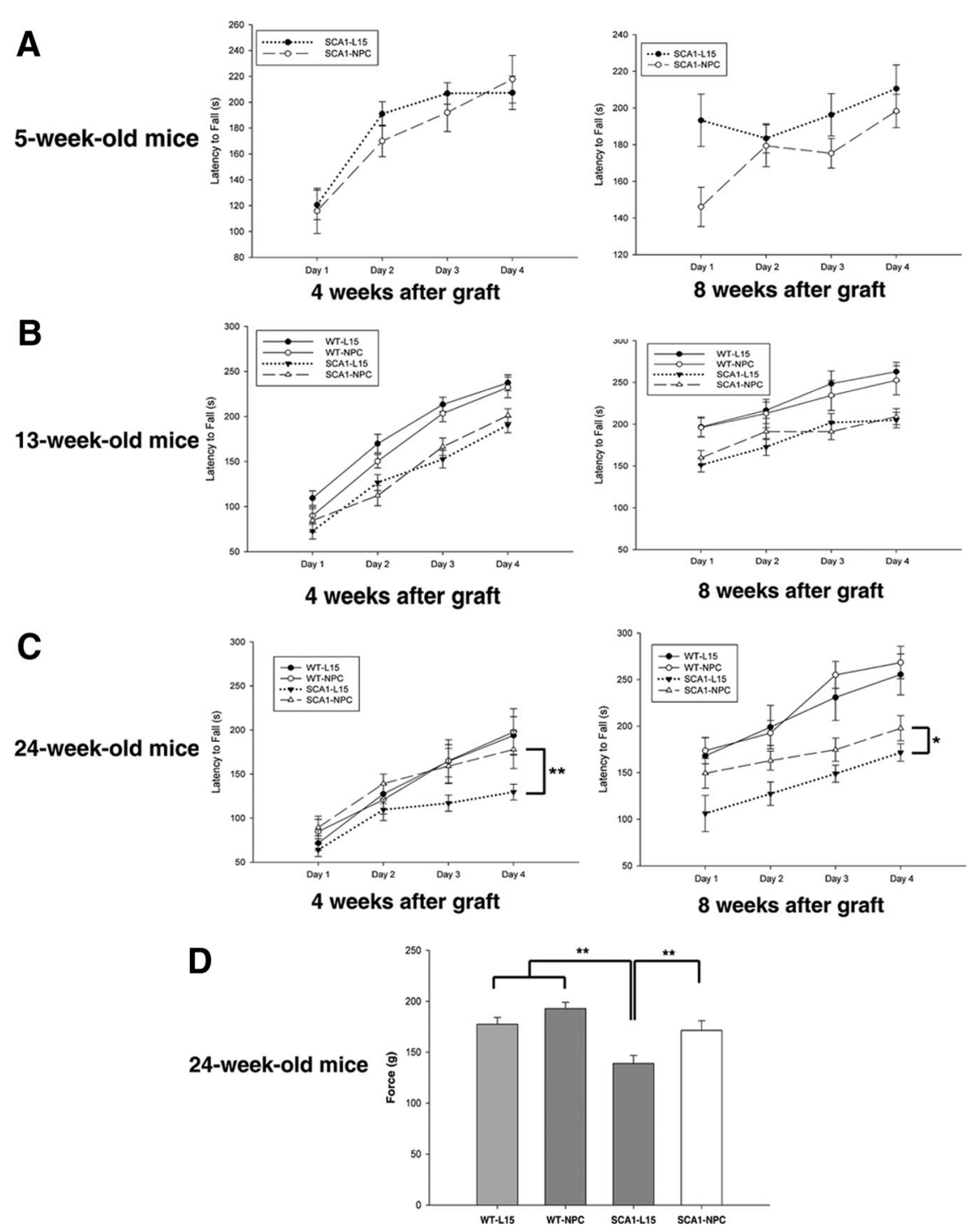

Figure 3. NPCs transplantation improves the motor behavior of SCA1 mice. Motor skills of SCA1 mice were assessed by rotating rod and grip strength meter. Mice underwent 4 trials per day on accelerating $(4-40 \mathrm{rpm}$ ) rotarod for 4 consecutive days 4 and 8 weeks after transplantation. There was no difference between SCA1-NPC and L15 mice when grafted at 5 and 13 weeks of age $(A, B)$. Twenty-four-week-old SCA1-NPC mice remained significantly longer on the rotating rod and showed better motor behavior than SCA1-L15 mice ( $($ ). Then mice were tested for their grip strength and force applied by them was measured on grip strength strength of SCA1-NPC mice was found to be significantly higher than sham mice. There was no significant difference between wild-type mice and SCA1-NPC mice (D). The results of both tests show that NPCs transplantation rescues ataxia. ${ }^{*} p<0.05$, ${ }^{* *} p<0.01$. One-way ANOVA followed by LSD-Fischer post hoc test was applied to obtain $p$ value.

Younger (5 and 13 weeks old at the time of transplantation) SCA1-NPC mice also had most of the grafted cells in the cerebellar white matter, with only few cells that migrated toward and into the cerebellar cortex (Fig. $6 B-E$ ). Conversely, in SCA1-NPC mice grafted at 24 weeks, many GFP ${ }^{\text {pos }}$ cells migrated from the white matter to all cerebellocortical layers and were found in close vicinity of PCs (Fig. 6F,G). Many grafted cells in the cerebellar cortex were in close contact with the host PCs with their processes wrapped around the PCs soma (see supplemental Video 4, available at www.jneurosci.org as supplemental material). Most of the grafted cells present in the white matter of SCA1 mice express GFAP and those in close contact with PCs had a neuronal morphology, and some of them expressed the mature neuronal marker NeuN (Fig. 6I; supplemental Fig. 3, available at www. jneurosci.org as supplemental material). 

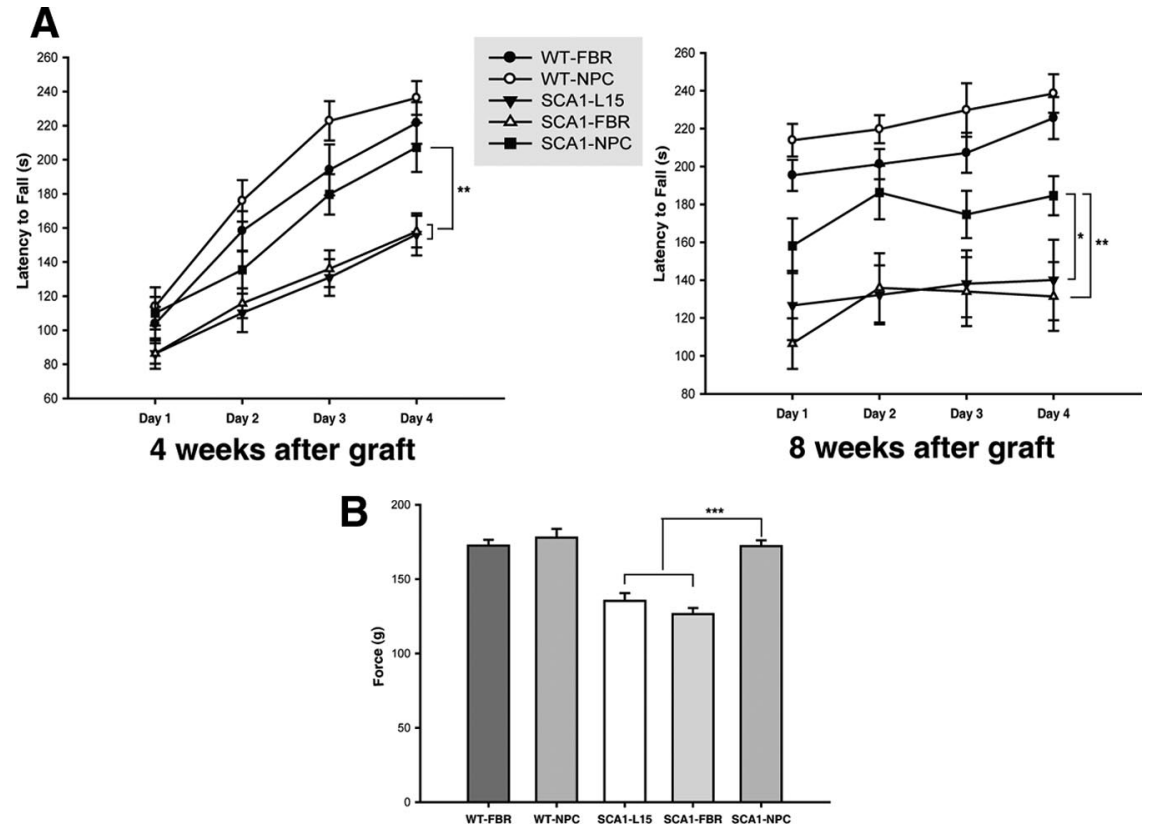

Figure 4. Non-neural cells did not improve the motor behavior of SCA1 mice. To assess the effect of non-neural cells on motor behavior of SCA1 mice, primary fibroblast cells were grafted in 24-week-old SCA1 mice and motor performance was tested on rotating $\operatorname{rod}(\boldsymbol{A})$ and grip strength meter $(\boldsymbol{B})$ as described in Figure 3. In contrast to NPCS, fibroblasts failed to improve motor performance of SCA1 mice in either of the test.

Table 1. Stereological estimates of total cerebellar Purkinje cells (values are in thousands)

\begin{tabular}{lcllr}
\hline Animal & WT & SCA1-L15 & SCA1-FBR & \multicolumn{1}{c}{ SCA1-NPC } \\
\hline Purkinje cell layer & & & & \\
$\# 1$ & $207.28(0.05)$ & $72.61(0.08)$ & $73.54(0.09)$ & $159.82(0.07)$ \\
$\# 2$ & $149.11(0.07)$ & $69.48(0.09)$ & $97.22(0.1)$ & $138.80(0.05)$ \\
$\# 3$ & $189.98(0.05)$ & $74.09(0.14)$ & $85.43(0.09)$ & $98.84(0.09)$ \\
$\# 4$ & $138.22(0.07)$ & $92.25(0.08)$ & $74.31(0.07)$ & $93.85(0.07)$ \\
$\# 5$ & $215.55(0.06)$ & $83.97(0.08)$ & & $122.62(0.07)$ \\
$\# 6$ & $221.52(0.05)$ & & & \\
Mean N (CE) $^{a}$ & $186.94(0.06)$ & $78.48(0.09)$ & $82.63(0.09)$ & $122.79(0.07)$ \\
V $^{b}$ & 0.19 & 0.12 & 0.13 & 0.22 \\
Granule cell and molecularlayer & & & \\
$\# 1$ & $1.44(0.81)$ & $36.55(0.1)$ & $19.76(0.17)$ & $23.55(0.22)$ \\
$\# 2$ & $2.41(0.51)$ & $15.93(0.21)$ & $26.83(0.15)$ & $11.34(0.27)$ \\
$\# 3$ & $0.9(\mathrm{I})$ & $34.76(0.14)$ & $31.19(0.14)$ & $13.69(0.18)$ \\
$\# 4$ & $7.69(0.3)$ & $20.37(0.2)$ & $23.50(0.13)$ & $14.63(0.19)$ \\
$\# 5$ & $0.97(1)$ & $24.69(0.18)$ & & $25.42(0.14)$ \\
$\# 6$ & $0.74(\mathrm{I})$ & & & \\
Mean N (CE) & $2.36(0.77)$ & $26.46(0.16)$ & $25.33(0.15)$ & $17.73(0.2)$ \\
CV $^{b}$ & 1.13 & 0.34 & 0.19 & 0.36 \\
\hline
\end{tabular}

${ }^{a} \mathrm{CE}=\mathrm{SEM} /$ mean, the estimated intra-animal coefficient of error.

${ }^{b} \mathrm{CV}=\mathrm{SD} /$ mean, the estimated interanimal coefficient of variation.

To quantify these observations, 8 weeks after transplantation, SCA1-NPC mice grafted at 5 and 13 weeks (no functional improvement), SCA1-NPC grafted at 24 weeks (functional improvement), and WT-NPC also grafted at 24 weeks were assessed for survival of the transplanted NPCs and distribution/migration in the cortex by stereological analysis (Table 2). In SCA1-NPC mice grafted when 24 weeks old, 34\% NPCs (out of 300,000 injected cells) survived. In SCA-NPC mice grafted when 5 and 13 weeks old, 22 and 26\%, respectively, of transplanted cells survived. The lowest survival was observed in WT animals. In SCA1NPC mice grafted when 24 weeks old, $~ 50 \%$ of surviving NPCs migrated to the cerebellar cortex, where $30 \%$ could be found in the molecular and PC layers. A much lower percentage of grafted NPCs migrated to these layers in the other groups (Table 2).

Overall, these findings confirm the notion that stem cells remain at the injection site when grafted into a normal brain or a brain with areas of only mild cell loss, but, when present, they migrate to areas of significant pathology, where they can survive, proliferate, and differentiate (Kelly et al., 2004).

\section{Grafted NPCs restore the basal membrane potential of Purkinje cells} We next investigated whether the behavioral and morphological improvement in SCA1-NPC mice grafted when 24 weeks old was accompanied by a detectable change in the electrophysiological properties of their PCs. We performed currentclamp recordings from PCs somata in cerebellar slices of SCA1-NPC, SCA1-L15, and wt mice 10 weeks after transplantation using the perforated patch whole-cell configuration of the patch-clamp technique (Horn and Marty, 1988). In these conditions, we detected a statistically significant difference in the minimal membrane potential of PCs of SCA1-NPC $(-60.4 \pm 2.2 \mathrm{mV}$, $n=7)$ versus SCA1-L15 mice $(-51.9 \pm 2.2 \mathrm{mV}, n=8)$ (Fig. 7). This slight hyperpolarization rendered the membrane potential of SCA1-NPC PCs close to the value found in wt animals of the same age $(-60.9 \pm 2.1 \mathrm{mV}, n=10)$.

\section{Discussion}

The observations of Sidman et al. (1959) and of Altman and Das (1965) revealed for the first time that neurogenesis takes place in the adult rodent brain. Reynolds and Weiss (1992) successfully isolated and expanded stem-like cells in vitro from adult mouse brain. These neural stem/progenitor cells can be grown in vitro as a population of continuously dividing precursors capable of generating neurons and glia. Despite this intrinsic regenerative capability, however, the CNS capacity to restore homeostasis in case of injury or degeneration remains inadequate. Transplantation of NSCs appears an appealing strategy to boost repair and regeneration in the brain, and adult NSCs has indeed provided functional improvement in animal models of neurological disease/ insult (Pluchino et al., 2003; Karimi-Abdolrezaee et al., 2006). The isolation from adult human brain of multipotent cells having the ability to generate neurons and glia (Johansson et al., 1999; Nunes et al., 2003; Westerlund et al., 2003; Sanai et al., 2004) has rendered such strategies applicable to human diseases, at least in principle. Implanted NSCs have been shown to functionally integrate into the parenchyma of various brain regions and generate diverse cell types (Pluchino et al., 2003; Kelly et al., 2004), including electrophysiologically active neurons (Auerbach et al., 2000; Englund et al., 2002) and myelin-forming oligodendrocytes (Snyder et al., 1997; Akiyama et al., 2001; Eftekharpour et al., 2007). In many cases, however, NSCs have promoted functional recovery not by replacing lost cells, but through a neuroprotective effect and by stimulating the host's regenerative capacity (Pluchino et al., 2005; Li et al., 2006; Redmond et al., 2007; Lee et al., 2008; Madhavan et al., 2008). 
In this study, we explored the ability of grafted NPCs to rescue the phenotype of a transgenic mouse model of SCA1. These animals have a primary PC pathology in the cerebellum, first characterized by physiological dysfunction, then by morphological changes without cell loss, and finally by progressive PC death. The investigation of this model allowed us to address several critical questions for stem cell therapy in cerebellar disorders. In this regard, it is conceivable that, while certain mechanisms of interaction between grafted NSCs and the receiving tissue may generally occur in the CNS, the cerebellum has neurobiological specificities that may imply some crucial differences.

First, we observed that grafted NPCs did not migrate to the cerebellar cortex if cell loss had not yet occurred. Dysfunctional or morphologically altered PCs, but in normal or nearly normal number, did not generate a strong enough signal to attract NPCs. The nature of the attractive signal is not determined, but we know that in other systems (basal ganglia, brain hemispheres), growth factors (Ghosh and Greenberg, 1995; Kuhn et al., 1997; Zhang et al., 2003) and chemokines (Imitola et al., 2004; Bantubungi et al., 2008) (S. Chintawar, A. Ravella, M. Pandolfo unpublished results) generated at the site of injury can act as a migratory and/or a prodifferentiating factor. Grafted NPCs that remained near the injection sites in the white matter generally adopted an astroglial phenotype and were GFAP ${ }^{\text {pos. }}$.

In older SCA1 mice, which had lost significant numbers of PCs, transplanted NPCs did migrate into the cerebellar cortex. None of these cells remained nestin ${ }^{\text {pos }}$, all expressed either astrocytic (GFAP ${ }^{\text {pos }}$ ) or neuronal $\left(\mathrm{NeuN}^{\mathrm{pos}}\right)$ differentiation markers. However, no grafted cell displayed a PC phenotype, as identified by overall morphology and expression of calbindin or L7. Therefore, no replacement of lost cells occurred in our experimental model. This is not surprising because, though there is ample evidence of maturation of grafted NPCs into electrophysiologically mature neurons, the process of establishing functional synapses takes months, without any guarantee that appropriate network connections are formed. Hence, the functional recovery observed in our model, and in other models in which stem cell transplantation has been beneficial without neuronal replacement taking place (Snyder et al., 2004; Lee et al., 2007c), is most likely explained by a neuroprotective effect on the host. In this study, evidence for a neuroprotective

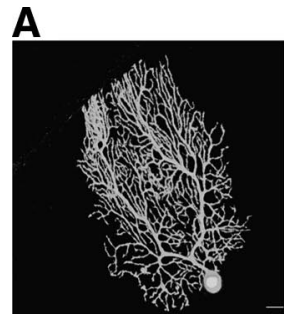

WT

B

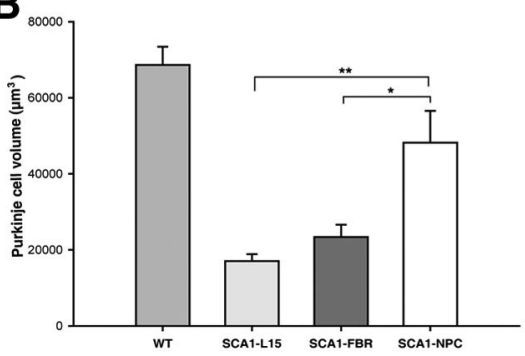

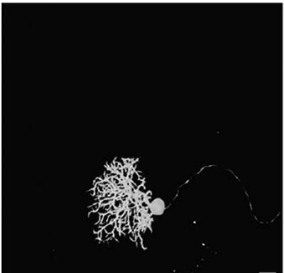

SCA1-FBR C

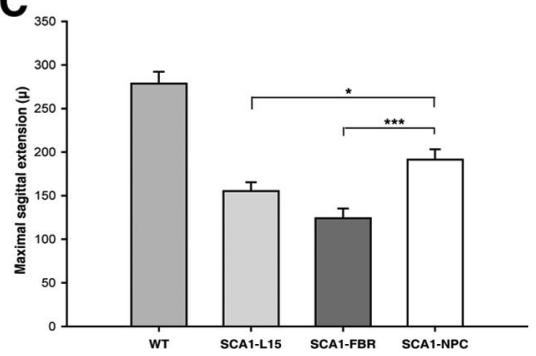

Figure 5. NPCs improve mutant Purkinje cell morphology and rescue mutant Purkinje cell dendritic arbors. Biocytinfilled PCs were immunostained and then acquired on confocal microscope. $A$, Representative PCs in WT $(n=5), \mathrm{SCA} 1-\mathrm{L} 15$ $(n=5)$, SCA1-FBR $(n=5)$, and SCA1-NPC $(n=9)$ mice are shown as projection images. $\boldsymbol{B}$, Volume of PCs in WT, SCA1-NPC, SCA1-L15, and SCA1-FBR mice. C, Sagittal extension of PC dendrites in WT, SCA1-NPC, SCA1-L15, and SCA1-FBR mice. Scale bars, $20 \mu \mathrm{m}$.
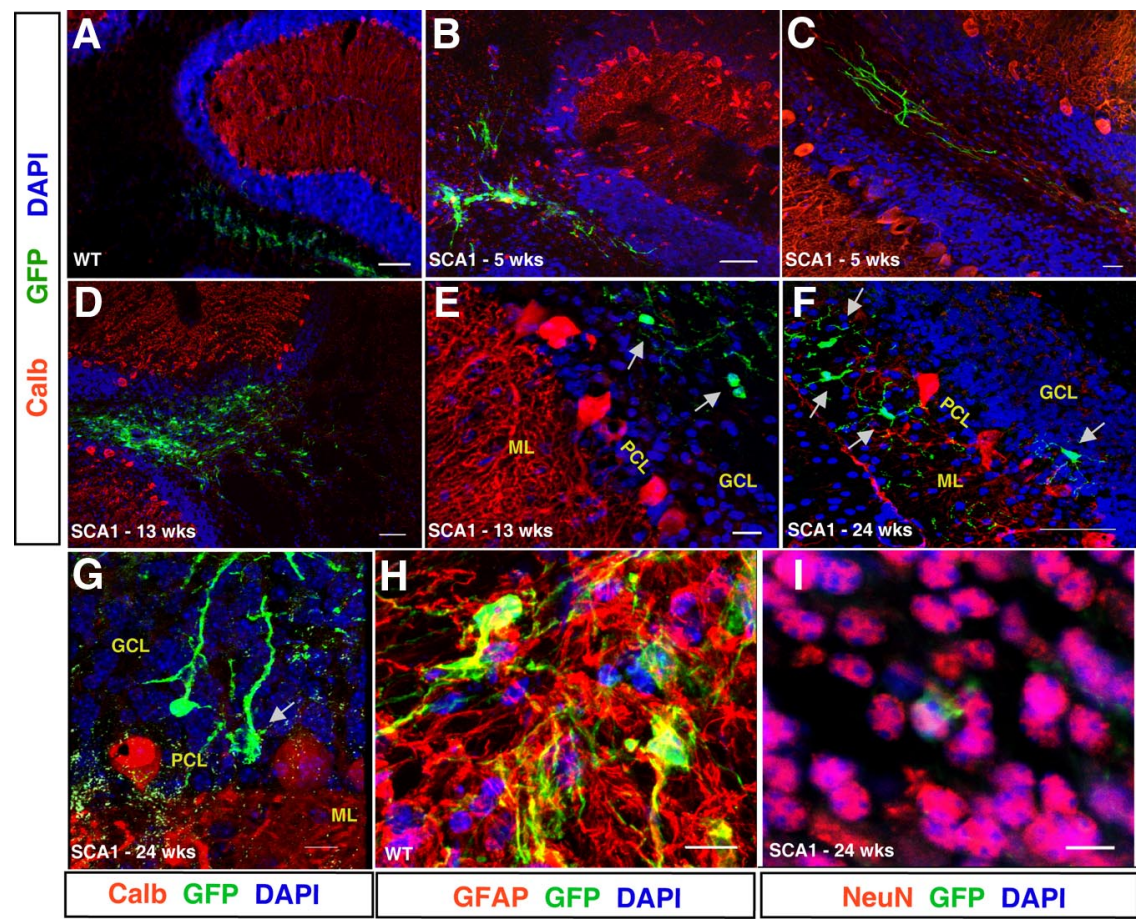

Figure 6. Engraftment of NPCs and derived cells. Eight weeks after transplantation, wt and SCA1 grafted animals were killed and the assessment of the graft was performed by confocal microscopy. Projection of $Z$ stack images of cerebellum double immunostained with GFP and calbindin show that in wt and SCA1 5-week-old grafted mice, NPCs migrate and remain in the white matter $(\boldsymbol{A}-\boldsymbol{C})$, whereas in SCA1 13-week-old grafted mice, few cells migrate to GCL but do not contact PC somata or dendrites ( $D$ and $\boldsymbol{E}$, see arrow). In SCA1 24-week-old grafted mice NPCs and derived cells home in to the site of degeneration and can be found in all cerebellocortical layers as represented in molecular layer $(\mathrm{ML})$ and granule cell layer $(\mathrm{GCL})(\boldsymbol{F})$ and in PC layer $(\mathrm{PCL})(\boldsymbol{G})(\mathrm{see}$ arrows). They remain in close vicinity of $P\left(s\right.$. GFP ${ }^{\text {pos }}$ donor-derived cells in any condition do not express Purkinje neuron-specific protein calbindin $(\boldsymbol{A}-\boldsymbol{G})$ but if migrated to the cortex sometimes coexpress mature neuron-specific protein NeuN $(\boldsymbol{I})$. NPCS migrating from site of injection and present in the white matter differentiate to astrocytes and express GFAP $(\boldsymbol{H})$. For quantitative data about the distribution of grafted cells in the cerebellar white matter and the cortex, refer to Table 2. Scale bars: $A, B, D, 50 \mu \mathrm{m}$; C, $E, 20 \mu \mathrm{m} ; \boldsymbol{F}-\mathbf{I}, 10 \mu \mathrm{m}$. 
Table 2. Stereological estimates of grafted NPC and derived cell survival and distribution in the cerebellar cortex (values are in thousands)

\begin{tabular}{|c|c|c|c|c|c|c|}
\hline Group & Animal & $\mathrm{ML}+\mathrm{PCL}$ & $\mathrm{GCL}$ & WM & Total & Survival (\%) \\
\hline \multirow[t]{4}{*}{ SCA1-5 weeks } & $\# 1$ & 1.55 (I) & $2.86(0.7)$ & $75.66(0.3)$ & $80.08(0.66)$ & 26.69 \\
\hline & $\# 2$ & $3.09(0.7)$ & $1.63(0.7)$ & $50.43(0.27)$ & $55.17(0.13)$ & 18.39 \\
\hline & \#3 & $6.86(0.34)$ & $9.29(0.36)$ & $44.72(0.25)$ & $60.88(0.31)$ & 20.30 \\
\hline & $\# 4$ & $5.0(0.38)$ & $9.79(0.34)$ & $63.45(0.27)$ & $78.25(0.33)$ & 26.09 \\
\hline Mean $N(\mathrm{CE})^{a}$ & & $4.13(0.61)$ & $5.89(0.52)$ & $58.56(0.27)$ & $68.59(0.35)$ & 22.87 \\
\hline $\mathrm{CV}^{b}$ & & 0.56 & 0.72 & 0.24 & 0.18 & 0.18 \\
\hline \multirow[t]{4}{*}{ SCA1-13 weeks } & $\# 1$ & $17.22(0.33)$ & $21.82(0.29)$ & $50.59(0.22)$ & $89.65(0.28)$ & 29.89 \\
\hline & $\# 2$ & $7.95(0.4)$ & $21.46(0.27)$ & $45.24(0.27)$ & $74.66(0.31)$ & 24.89 \\
\hline & \#3 & $9.26(0.37)$ & $17.97(0.35)$ & $40.95(0.24)$ & $68.18(0.32)$ & 22.73 \\
\hline & $\# 4$ & $2.58(0.31)$ & $10.06(0.47)$ & $68.49(0.25)$ & $81.14(0.34)$ & 27.05 \\
\hline $\operatorname{Mean} N(C E)^{a}$ & & $9.25(0.35)$ & $17.83(0.34)$ & $51.32(0.24)$ & $78.41(0.31)$ & 26.14 \\
\hline $\mathrm{CV}^{b}$ & & 0.65 & 0.31 & 0.24 & 0.12 & 0.12 \\
\hline \multirow[t]{4}{*}{ SCA1-24 weeks } & $\# 1$ & $31.46(0.2)$ & $23.75(0.19)$ & $69.38(0.26)$ & $124.60(0.21)$ & 41.54 \\
\hline & $\# 2$ & $25.84(0.21)$ & $20.84(0.22)$ & $52.56(0.16)$ & $99.25(0.19)$ & 33.09 \\
\hline & \#3 & $35.61(0.31)$ & $14.31(0.33)$ & $38.18(0.25)$ & $88.11(0.29)$ & 29.37 \\
\hline & $\# 4$ & $37.79(0.22)$ & $23.51(0.24)$ & $60.95(0.19)$ & $122.27(0.21)$ & 40.76 \\
\hline Mean $N(\mathrm{CE})^{a}$ & & $32.67(0.23)$ & $20.61(0.24)$ & $55.27(0.21)$ & $108.56(0.22)$ & 36.19 \\
\hline $\mathrm{CV}^{b}$ & & 0.16 & 0.21 & 0.24 & 0.16 & 0.16 \\
\hline \multirow[t]{4}{*}{ WT-24 weeks } & $\# 1$ & $3.54(0.48)$ & $0.92(0.73)$ & $21.77(0.34)$ & $26.24(0.48)$ & 8.75 \\
\hline & $\# 2$ & $2.28(0.97)$ & $0.96(0.73)$ & $18.18(0.49)$ & $21.43(0.73)$ & 7.1 \\
\hline & \#3 & $4.50(0.51)$ & $2.31(0.59)$ & $31.75(0.38)$ & $38.57(0.49)$ & 12.9 \\
\hline & $\# 4$ & $4.35(0.49)$ & $3.41(0.53)$ & $47.65(0.47)$ & $55.42(0.49)$ & 18.5 \\
\hline Mean $N(\mathrm{CE})^{a}$ & & $3.67(0.61)$ & $1.9(0.64)$ & $20.61(0.42)$ & $35.41(0.54)$ & 11.8 \\
\hline $\mathrm{CV}^{b}$ & & 0.28 & 1.91 & 0.44 & 0.43 & 0.43 \\
\hline
\end{tabular}

Distribution/migration/homing of grafted NPCs. ML, Molecular layer; PCL, Purkinje cell layer; GCL, granule cell layer; WM, white matter.

${ }^{a} \mathrm{CE}=\mathrm{SEM} /$ mean, the estimated intra-animal coefficient of error.

${ }^{b} \mathrm{CV}=\mathrm{SD} /$ mean, the estimated interanimal coefficient of variation.

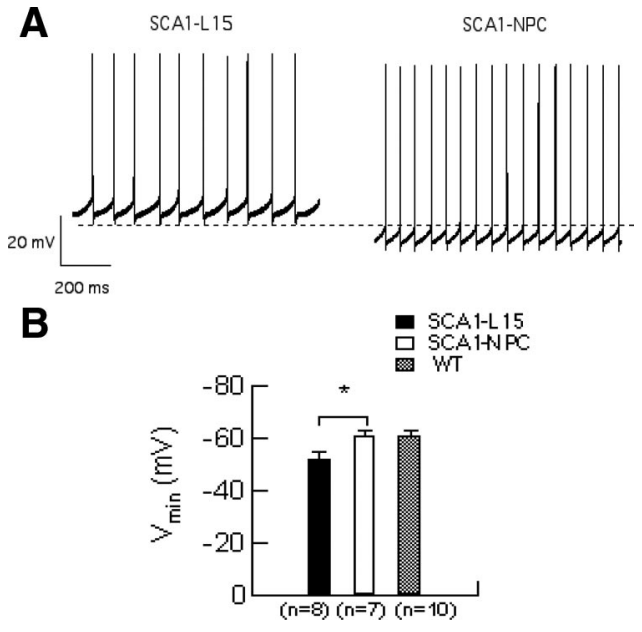

Figure 7. Restoration of the basal level of membrane potential in SCA1-NPC mice Purkinje cells. $\boldsymbol{A}$, Minimal potential during current-clamp recordings is restored in the Purkinje cells of the treated animals. $\boldsymbol{B}$, Corresponding histogram reports a significant hyperpolarization in SCA1-NPC mice Purkinje cells compared with the cells recorded in the SCA1-L15 animals ( $p<$ $0.05)$, restoring similar levels of potential as in the wild type.

effect came, in addition to motor behavior improvement, from stereological and electrophysiological analyses. Stereological analysis of the cerebellar cortex revealed that grafted animals had more surviving PCs and a better preserved morphology of these cells than the control groups, and the organization of the cerebellar cortex in three distinct layers appears to be preserved. Electrophysiology, studied by perforated patch clamp, revealed that PCs of SCA1 mice at 34 weeks of age (when killed 10 weeks after NPCs transplantation) show a significant reduction of minimal membrane potential leading to a potential level close to wt mice of the same age. This reduction was not found in control (sham- and fibroblast-grafted) animals, indi- cating that NPCs transplantation had provoked an improvement in PCs' capacity to establish and maintain a normal membrane potential, an essential element of neuronal excitability.

The mechanisms involved in the neuroprotective effect of NPCs in B05/SCA1 mice have yet to be fully identified. The release of growth factors or cytokines has been invoked in a number of models (Lu et al., 2003; Pluchino et al., 2003; Lee et al., 2007b), but we could not find a direct evidence that levels of BDNF, GDNF, NGF, or NT-3 were increased in the cerebella of grafted animals. However, despite these negative findings, we cannot exclude that a discrete, localized release of neurotrophic substances occurred. Direct contact between grafted and host cells is another possible explanation for the observed morphological and functional rescue. Observation of confocal images indeed often showed close contact between GFP ${ }^{\text {pos }}$ grafted cells and host PCs. In some cases, processes emanating from a GFP ${ }^{\text {pos }}$ cell appeared to wrap around a PC body and contact its dendrites. A body of evidence from previous studies indicates that the formation of functional synapses by neurons derived from grafted stem cells takes much longer than the time for functional and morphological improvement in our model system, thus we think it is very unlikely that the observed contacts contain mature electrochemical synapses. In a related study (J. Jäderstad, L. M. Jäderstad, J. Li, S. Chintawar, C. Salto, Y. D. Teng, M. Pandolfo, V. Ourednik, R. L. Sidman, E. Arenas, E. Y. Snyder, E. Herlenius, unpublished results), we obtained evidence from organotypic cultures and from this and other animal models, that the neuroprotective effect of stem cells is at least partly mediated by the formation of gap junctions, possibly by allowing electrical coupling and direct exchange of trophic factors between grafted and host cells. This may represent therefore an important, possibly the major mechanism involved in the rescue effect of NPCs in old B05/SCA1 mice.

In conclusion, transplantation of NPCs in the cerebellar white matter of a mouse model of the neurodegenerative disease SCA1, 
that primarily targets PCs, resulted in behavioral, morphological, and electrophysiological improvement only if performed when significant PC loss has occurred.

\section{References}

Akiyama Y, Honmou O, Kato T, Uede T, Hashi K, Kocsis JD (2001) Transplantation of clonal neural precursor cells derived from adult human brain establishes functional peripheral myelin in the rat spinal cord. Exp Neurol 167:27-39.

Altman J, Das GD (1965) Post-natal origin of microneurones in the rat brain. Nature 207:953-956.

Auerbach JM, Eiden MV, McKay RD (2000) Transplanted CNS stem cells form functional synapses in vivo. Eur J Neurosci 12:1696-1704.

Bantubungi K, Blum D, Cuvelier L, Wislet-Gendebien S, Rogister B, Brouillet E, Schiffmann SN (2008) Stem cell factor and mesenchymal and neural stem cell transplantation in a rat model of Huntington's disease. Mol Cell Neurosci 37:454-470.

Bowman AB, Lam YC, Jafar-Nejad P, Chen HK, Richman R, Samaco RC, Fryer JD, Kahle JJ, Orr HT, Zoghbi HY (2007) Duplication of Atxn1l suppresses SCA1 neuropathology by decreasing incorporation of polyglutamineexpanded ataxin-1 into native complexes. Nat Genet 39:373-379.

Burright EN, Clark HB, Servadio A, Matilla T, Feddersen RM, Yunis WS, Duvick LA, Zoghbi HY, Orr HT (1995) SCA1 transgenic mice: a model for neurodegeneration caused by an expanded CAG trinucleotide repeat. Cell 82:937-948.

Clark HB, Burright EN, Yunis WS, Larson S, Wilcox C, Hartman B, Matilla A, Zoghbi HY, Orr HT (1997) Purkinje cell expression of a mutant allele of SCA1 in transgenic mice leads to disparate effects on motor behaviors, followed by a progressive cerebellar dysfunction and histological alterations. J Neurosci 17:7385-7395.

Corti S, Locatelli F, Papadimitriou D, Del Bo R, Nizzardo M, Nardini M, Donadoni C, Salani S, Fortunato F, Strazzer S, Bresolin N, Comi GP (2007) Neural stem cells LewisX+ CXCR4+ modify disease progression in an amyotrophic lateral sclerosis model. Brain 130:1289-1305.

Corti S, Nizzardo M, Nardini M, Donadoni C, Salani S, Ronchi D, Saladino F, Bordoni A, Fortunato F, Del Bo R, Papadimitriou D, Locatelli F, Menozzi G, Strazzer S, Bresolin N, Comi GP (2008) Neural stem cell transplantation can ameliorate the phenotype of a mouse model of spinal muscular atrophy. J Clin Invest 118:3316-3330.

Cummings BJ, Uchida N, Tamaki SJ, Salazar DL, Hooshmand M, Summers R, Gage FH, Anderson AJ (2005) Human neural stem cells differentiate and promote locomotor recovery in spinal cord-injured mice. Proc Natl Acad Sci U S A 102:14069-14074.

D’Angelo E, Nieus T, Maffei A, Armano S, Rossi P, Taglietti V, Fontana A, Naldi G (2001) Theta-frequency bursting and resonance in cerebellar granule cells: experimental evidence and modeling of a slow $\mathrm{K}^{+}$dependent mechanism. J Neurosci 21:759-770.

Eftekharpour E, Karimi-Abdolrezaee S, Wang J, El Beheiry H, Morshead C, Fehlings MG (2007) Myelination of congenitally dysmyelinated spinal cord axons by adult neural precursor cells results in formation of nodes of Ranvier and improved axonal conduction. J Neurosci 27:3416-3428.

Englund U, Bjorklund A, Wictorin K, Lindvall O, Kokaia M (2002) Grafted neural stem cells develop into functional pyramidal neurons and integrate into host cortical circuitry. Proc Natl Acad Sci U S A 99:17089-17094.

Gage FH (2002) Neurogenesis in the adult brain. J Neurosci 22:612-613.

Geuna S (2000) Appreciating the difference between design-based and model-based sampling strategies in quantitative morphology of the nervous system. J Comp Neurol 427:333-339.

Ghosh A, Greenberg ME (1995) Distinct roles for bFGF and NT-3 in the regulation of cortical neurogenesis. Neuron 15:89-103.

Gritti A, Parati EA, Cova L, Frolichsthal P, Galli R, Wanke E, Faravelli L, Morassutti DJ, Roisen F, Nickel DD, Vescovi AL (1996) Multipotential stem cells from the adult mouse brain proliferate and self-renew in response to basic fibroblast growth factor. J Neurosci 16:1091-1100.

Gritti A, Frölichsthal-Schoeller P, Galli R, Parati EA, Cova L, Pagano SF, Bjornson CR, Vescovi AL (1999) Epidermal and fibroblast growth factors behave as mitogenic regulators for a single multipotent stem cell-like population from the subventricular region of the adult mouse forebrain. J Neurosci 19:3287-3297.

Horn R, Marty A (1988) Muscarinic activation of ionic currents measured by a new whole-cell recording method. J Gen Physiol 92:145-159.

Imitola J, Raddassi K, Park KI, Mueller FJ, Nieto M, Teng YD, Frenkel D, Li J,
Sidman RL, Walsh CA, Snyder EY, Khoury SJ (2004) Directed migration of neural stem cells to sites of CNS injury by the stromal cell-derived factor 1alpha/CXC chemokine receptor 4 pathway. Proc Natl Acad Sci U S A 101:18117-18122.

Jeong SW, Chu K, Jung KH, Kim SU, Kim M, Roh JK (2003) Human neural stem cell transplantation promotes functional recovery in rats with experimental intracerebral hemorrhage. Stroke 34:2258-2263.

Johansson CB, Svensson M, Wallstedt L, Janson AM, Frisén J (1999) Neural stem cells in the adult human brain. Exp Cell Res 253:733-736.

Karimi-Abdolrezaee S, Eftekharpour E, Wang J, Morshead CM, Fehlings MG (2006) Delayed transplantation of adult neural precursor cells promotes remyelination and functional neurological recovery after spinal cord injury. J Neurosci 26:3377-3389.

Kelly S, Bliss TM, Shah AK, Sun GH, Ma M, Foo WC, Masel J, Yenari MA, Weissman IL, Uchida N, Palmer T, Steinberg GK (2004) Transplanted human fetal neural stem cells survive, migrate, and differentiate in ischemic rat cerebral cortex. Proc Natl Acad Sci U S A 101:11839-11844.

Kubínová L, Janácek J (2001) Confocal microscopy and stereology: estimating volume, number, surface area and length by virtual test probes applied to three-dimensional images. Microsc Res Tech 53:425-435.

Kuhn HG, Winkler J, Kempermann G, Thal LJ, Gage FH (1997) Epidermal growth factor and fibroblast growth factor-2 have different effects on neural progenitors in the adult rat brain. J Neurosci 17:5820-5829.

Lee HJ, Kim KS, Park IH, Kim SU (2007a) Human neural stem cells overexpressing VEGF provide neuroprotection, angiogenesis and functional recovery in mouse stroke model. PLoS ONE 2:e156.

Lee HJ, Kim KS, Kim EJ, Choi HB, Lee KH, Park IH, Ko Y, Jeong SW, Kim SU (2007b) Brain transplantation of immortalized human neural stem cells promotes functional recovery in mouse intracerebral hemorrhage stroke model. Stem Cells 25:1204-1212.

Lee JP, Jeyakumar M, Gonzalez R, Takahashi H, Lee PJ, Baek RC, Clark D, Rose H, Fu G, Clarke J, McKercher S, Meerloo J, Muller FJ, Park KI, Butters TD, Dwek RA, Schwartz P, Tong G, Wenger D, Lipton SA, et al. (2007c) Stem cells act through multiple mechanisms to benefit mice with neurodegenerative metabolic disease. Nat Med 13:439-447.

Lee ST, Chu K, Jung KH, Kim SJ, Kim DH, Kang KM, Hong NH, Kim JH, Ban JJ, Park HK, Kim SU, Park CG, Lee SK, Kim M, Roh JK (2008) Antiinflammatory mechanism of intravascular neural stem cell transplantation in haemorrhagic stroke. Brain 131:616-629.

Li J, Imitola J, Snyder EY, Sidman RL (2006) Neural stem cells rescue nervous Purkinje neurons by restoring molecular homeostasis of tissue plasminogen activator and downstream targets. J Neurosci 26:7839-7848.

Lie DC, Song H, Colamarino SA, Ming GL, Gage FH (2004) Neurogenesis in the adult brain: new strategies for central nervous system diseases. Annu Rev Pharmacol Toxicol 44:399-421.

Lu P, Jones LL, Snyder EY, Tuszynski MH (2003) Neural stem cells constitutively secrete neurotrophic factors and promote extensive host axonal growth after spinal cord injury. Exp Neurol 181:115-129.

Madhavan L, Ourednik V, Ourednik J (2008) Neural stem/progenitor cells initiate the formation of cellular networks that provide neuroprotection by growth factor-modulated antioxidant expression. Stem Cells 26:254-265.

McBride JL, Behrstock SP, Chen EY, Jakel RJ, Siegel I, Svendsen CN, Kordower JH (2004) Human neural stem cell transplants improve motor function in a rat model of Huntington's disease. J Comp Neurol 475:211-219.

Morshead CM, Reynolds BA, Craig CG, McBurney MW, Staines WA, Morassutti D, Weiss S, van der Kooy D (1994) Neural stem cells in the adult mammalian forebrain: a relatively quiescent subpopulation of subependymal cells. Neuron 13:1071-1082.

Nunes MC, Roy NS, Keyoung HM, Goodman RR, McKhann G 2nd, Jiang L, Kang J, Nedergaard M, Goldman SA (2003) Identification and isolation of multipotential neural progenitor cells from the subcortical white matter of the adult human brain. Nat Med 9:439-447.

Orr HT, Zoghbi HY (2007) Trinucleotide repeat disorders. Annu Rev Neurosci 30:575-621.

Pluchino S, Quattrini A, Brambilla E, Gritti A, Salani G, Dina G, Galli R, Del Carro U, Amadio S, Bergami A, Furlan R, Comi G, Vescovi AL, Martino G (2003) Injection of adult neurospheres induces recovery in a chronic model of multiple sclerosis. Nature 422:688-694.

Pluchino S, Zanotti L, Rossi B, Brambilla E, Ottoboni L, Salani G, Martinello M, Cattalini A, Bergami A, Furlan R, Comi G, Constantin G, Martino G 
(2005) Neurosphere-derived multipotent precursors promote neuroprotection by an immunomodulatory mechanism. Nature 436:266-271.

Redmond DE Jr, Bjugstad KB, Teng YD, Ourednik V, Ourednik J, Wakeman DR, Parsons XH, Gonzalez R, Blanchard BC, Kim SU, Gu Z, Lipton SA, Markakis EA, Roth RH, Elsworth JD, Sladek JR Jr, Sidman RL, Snyder EY (2007) Behavioral improvement in a primate Parkinson's model is associated with multiple homeostatic effects of human neural stem cells. Proc Natl Acad Sci U S A 104:12175-12180.

Reynolds BA, Weiss S (1992) Generation of neurons and astrocytes from isolated cells of the adult mammalian central nervous system. Science 255:1707-1710.

Roberts TJ, Price J, Williams SC, Modo M (2006) Preservation of striatal tissue and behavioral function after neural stem cell transplantation in a rat model of Huntington's disease. Neuroscience 139:1187-1199.

Roth A, Häusser M (2001) Compartmental models of rat cerebellar Purkinje cells based on simultaneous somatic and dendritic patch-clamp recordings. J Physiol 535:445-472.

Sanai N, Tramontin AD, Quiñones-Hinojosa A, Barbaro NM, Gupta N, Kunwar S, Lawton MT, McDermott MW, Parsa AT, Manuel-García Verdugo J, Berger MS, Alvarez-Buylla A (2004) Unique astrocyte ribbon in adult human brain contains neural stem cells but lacks chain migration. Nature 427:740-744.

Sidman RL, Miale IL, Feder N (1959) Cell proliferation and migration in the primitive ependymal zone: an autoradiographic study of histogenesis in the nervous system. Exp Neurol 1:322-333.

Snyder EY, Yoon C, Flax JD, Macklis JD (1997) Multipotent neural precursors can differentiate toward replacement of neurons undergoing targeted apoptotic degeneration in adult mouse neocortex. Proc Natl Acad Sci U S A 94:11663-11668.

Snyder EY, Daley GQ, Goodell M (2004) Taking stock and planning for the next decade: realistic prospects for stem cell therapies for the nervous system. J Neurosci Res 76:157-168.

Taupin P, Gage FH (2002) Adult neurogenesis and neural stem cells of the central nervous system in mammals. J Neurosci Res 69:745-749.

von Bartheld C (2002) Counting particles in tissue sections: choices of methods and importance of calibration to minimize biases. Histol Histopathol 17:639-648.

Watase K, Weeber EJ, Xu B, Antalffy B, Yuva-Paylor L, Hashimoto K, Kano M, Atkinson R, Sun Y, Armstrong DL, Sweatt JD, Orr HT, Paylor R, Zoghbi HY (2002) A long CAG repeat in the mouse Scal locus replicates SCA1 features and reveals the impact of protein solubility on selective neurodegeneration. Neuron 34:905-919.

Weiss S, Reynolds BA, Vescovi AL, Morshead C, Craig CG, van der Kooy D (1996) Is there a neural stem cell in the mammalian forebrain? Trends Neurosci 19:387-393.

Westerlund U, Moe MC, Varghese M, Berg-Johnsen J, Ohlsson M, Langmoen IA, Svensson M (2003) Stem cells from the adult human brain develop into functional neurons in culture. Exp Cell Res 289:378-383.

Yasuhara T, Matsukawa N, Hara K, Yu G, Xu L, Maki M, Kim SU, Borlongan CV (2006) Transplantation of human neural stem cells exerts neuroprotection in a rat model of Parkinson's disease. J Neurosci 26:12497-12511.

Zhang H, Vutskits L, Pepper MS, Kiss JZ (2003) VEGF is a chemoattractant for FGF-2-stimulated neural progenitors. J Cell Biol 163:1375-1384. 